\title{
UBIKACIJA UTVRDE RIBNICA IZ PUTOPISA EVLIJE ČELEBIJA*
}

\author{
Šime VRKIĆ \\ Odjel za turizam i komunikacijske znanosti \\ Sveučilište u Zadru
}

\author{
UDK: $910.4(091): 623.1$ \\ DOI: https://dx.doi.org/10.21857/mjrl3uxg09 \\ Izvorni znanstveni rad \\ Prihvaćeno: 29. svibnja 2019.
}

U radu se donosi prijedlog ubikacije utvrde Ribnica (Ribniçse), čije je osvajanje detaljno opisao poznati osmanski putopisac Evlija Čelebi u svojem djelu Putopis, koje se još jedanput potvrdilo kao iznimno vjerodostojan izvor za povijest hrvatskih zemalja u osmanskom razdoblju. Ribnica se identificira s poznatom utvrdom Kaštel Andreis (Castel Andreis), čiji se ostatci nalaze u naselju Jadrtovac kod Šibenika. Njezinom je identifikacijom omogućena detaljnija rekonstrukcija osmanskog napada na područje Morinjskog zaljevu u ljeto 1660. godine, koji je do sada bio poznat samo po kratkim zabilješkama suvremenih povjesničara. Zapovjednik obrane utvrde uskok Šarić (şarik) identificira se s poznatim harambašom Cvitkom Šarićem, serdarom i zapovjednikom šibenskih Morlaka iz razdoblja Kandijskog rata.

Ključne riječi: Evlija Čelebi, Kandijski rat, harambaša Cvitko Šarić, Morinjski zaljev, Jadrtovac, Kaštel Andreis, Prigrada.

\section{UVOD}

Evlija Čelebi (1611. - 1682.), punim imenom Evliyâ Çelebi bin Derviş Mehemmed Zillî, poznati je osmanski putopisac iz 17. stoljeća čije djelo pod nazivom Seyâhatnâme (Putopis) sadrži opise njegovih putovanja po mnogim dijelovima Osmanskog Carstva, uključujući i neka pogranična područja izvan njega. Djelo se sastoji od deset opsežnih svezaka, a najviše podataka o hrvatskom području nalazi se u petom, šestom i sedmom svesku. Tijekom 1660-ih godina Evlija je bio izravni sudionik nekih povijesnih događaja na području Hrvatske, čiji je teritorij u to vrijeme bio podijeljen između Habsburške Monarhije, Mletačke Republike i Osmanskog Carstva. Unatoč kontroverzama koje su dugo pratile njegovo djelo, Putopis se potvrdio kao prvorazredan izvor pouzdanih povijesnih, geografskih i etnografskih podataka iz 17. stoljeća. ${ }^{1}$

* Ovaj je rad sufinancirala Hrvatska zaklada za znanost projektom Kulturni krajolik - model valorizacije, zaštite, upravljanja i korištenja kulturne baštine - ProHeritage (UIP-2017-05-2152).

1 Najnoviji pregled života i djela Evlije Čelebija te o njegovoj važnosti za hrvatsku historiografiju vidi u: Nenad MoaČAnin, Kornelija JuRIn StarČEvić, „Novi“ Evlija Čelebi: autograf „Putopisa“, Književna smotra, br. 173, Zagreb, 2014., 77 - 90. 
Do sada se u hrvatskoj znanosti ponajviše koristio prijevod koji je 1950-ih godina napravio bosansko-hercegovački orijentalist Hazim Šabanović, prevevši dijelove Putopisa koji su se odnosili na jugoslavenske zemlje. ${ }^{2}$ Njegov se prijevod temeljio na djelu iz kojega su izdavači izostavili mnoge dijelove teksta, a brojne pogreške, koje su sve do nedavno pripisivane Evliji, nastajale su prilikom kasnijih prijepisa, prevođenja i tiskanja. ${ }^{3}$ Zadnjih nekoliko desetljeća pronađeno je više rukopisnih verzija Putopisa, od kojih se jedna smatra izvornim Evlijinim rukopisom, odnosno autografom. Između 1998. i 2007. godine na latiničkom je prijepisu objavljeno svih deset svezaka pronađenih rukopisa. ${ }^{4}$ Novo izdanje omogućava provjeru podataka iz Šabanovićeva prijevoda, a mnogi dijelovi teksta sadrže podatke koji do sada nisu bili poznati. ${ }^{5} \mathrm{Na}$ taj se način došlo do novih spoznaja o povijesti hrvatskih zemalja u osmanskom razdoblju, kao što su primjerice one o obitelji Zrinski. ${ }^{6}$

Čitajući Putopis, pažnju mi je privukao opis jedne manje ratne epizode sa šibenskog područja, u kojoj se lokalno stanovništvo sklonilo u ograđeni vinograd iz kojega su pokušali pružiti otpor nadmoćnijim osmanskim napadačima. Kao arheologa zaintrigirao me opis zidova vinograda, za koje je navedeno da su bili veliki kao bedemi.7 Pretpostavljajući da bi se moglo raditi o ostatcima prapovijesne gradine, upustio sam se u pokušaj ubiciranja navedenog lokaliteta. Budući da se navedeni događaj zbio prilikom osvajanja grada ili utvrde Rinice, odnosno utvrde Ribnice (Ribniçse), neophodno je bilo ubicirati taj lokalitet. ${ }^{8}$

Do sada je u stručnoj literaturi bilo nekoliko prijedloga ubikacije ove utvrde, a prvi koji se osvrnuo na to pitanje bio je prevoditelj H. Šabanović, koji je zbog blizine Šibenika i sličnosti u imenima u više bilješki naveo da se vjerojatno radi o Rakitnici ili Rogoznici. ${ }^{9}$ Na problem ubiciranja ove utvrde kratko se osvrnuo

2 Evlija ČelebI, Putopis. Odlomci o jugoslovenskim zemljama (preveo Hazim Šabanović), Sarajevo, 1967.

3 Marta ANDrić, Simpozij o Evliji Čelebiju, Scrinia Slavonica, sv. 12, Slavonski Brod, 2012., 377 - 380.

4 M. ANDrić, Simpozij o Evliji Čelebiju, 378.

5 N. Moačanin, K. Jurin StarČEvić, „Novi“ Evlija Čelebi, 81.

6 Anđelko Vlašıć, Obitelj Zrinski u Putopisu Evlije Čelebija i usporedba s neosmanskim izvorima, Povijesni prilozi, sv. 52, Zagreb, 2017., 29 - 52.

E. ČEleBI, Putopis, 185.

8 H. Šabanović je u prijevodu koristio naziv grad ili utvrda Rinica, s time da je u napomeni naveo da se u originalu s kojega je prevodio navodi ime $R-y-n-c^{-}-s-h$, što bi se prema njemu moglo čitati kao Rinica, Rinča ili slično: E. ČELEBI, Putopis,183, bilj. 19. U objavljenom autografu (peti svezak objavljen je 2001. godine), ime mjesta navodi se kao kal'a-i Ribniçse, što se može čitati kao utvrda Ribnica: Evliyâ Çelebi Bın Derviş Menemmed Zıllî, Evliyâ Çelebi Seyahatnâmesi Topkapı Sarayı Kütüphanesi Bağdat 307 Numaralı Yazmanın Transkripsiyonu - Dizini, (priredili Yücel Dağli, Seyit Ali Kahraman, İbrahim Sezgin), sv. V. Istanbul, 2001., 246, 248, 252, 278 i 285.

$9 \quad$ E. ČeleBI, Putopis, 183, bilj. 19; 193, bilj. 6, 8 i 194, bilj. 17. 


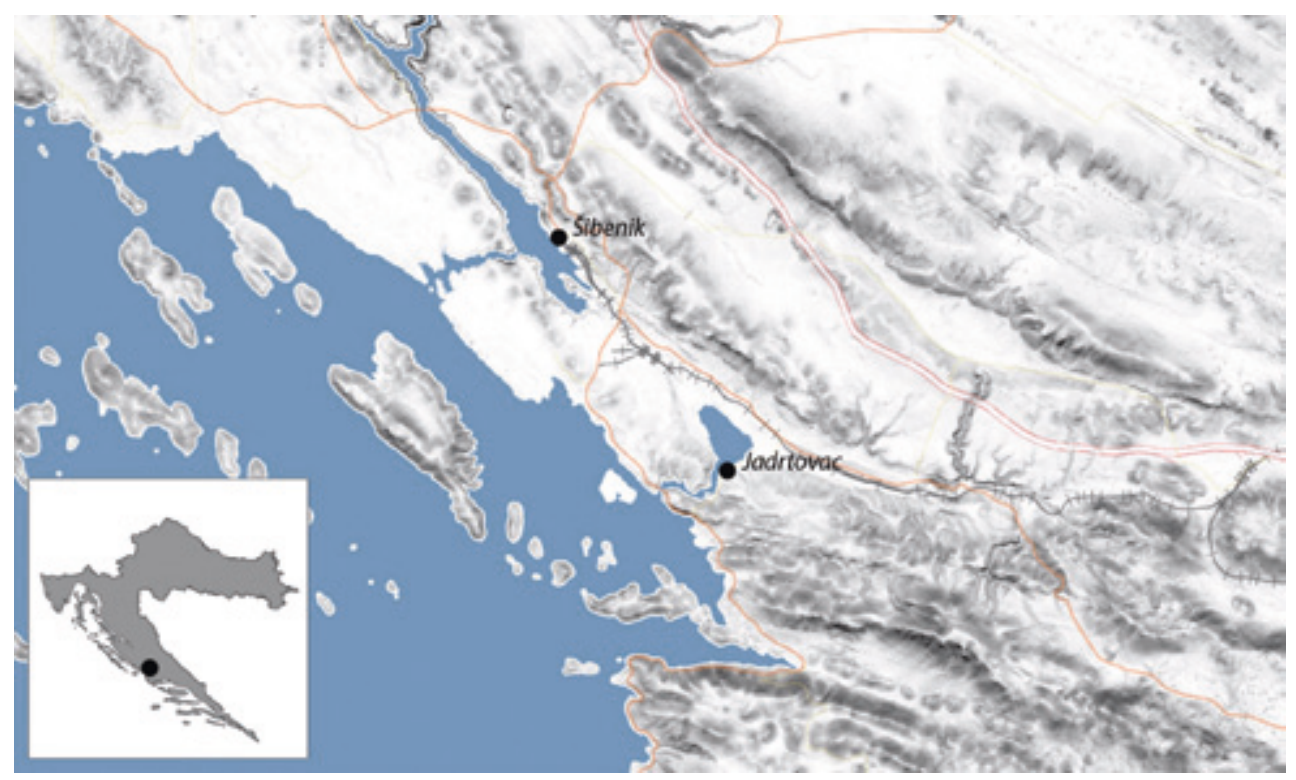

KARTA 1. Karta s označenim položajem Jadrtovca kod Šibenika (izradio: Šime Vrkić; podloga: geoportal.dgu.hr)

i naš ugledni povjesničar Nenad Moačanin, navodeći da se „Rinica“ spominje u popisu defterdara iz 1702. godine, i to kao bivša turska utvrda, ali unatoč tomu što je Putopis smješta u blizinu Šibenika, navodi da je možda veća vjerojatnost da se nalazila negdje oko Maslenice. ${ }^{10}$ To je potaknulo lokalnog povjesničara Tomislava Šarliju da Rinicu smjesti na utvrdu Dračevac u Jasenicama, ${ }^{11}$ a kao drugu moguću lokaciju naveo je ostatke utvrde Šibenik u kanjonu rijeke Zrmanje, nedaleko od njezina ušća u Novigradsko more. ${ }^{12}$

Polazeći od pretpostavke da su Evlijini geografski podatci i opisi prilično vjerodostojni i koristeći se internetskim servisom Google Earth, počeo sam pregledavati manje morske zaljeve na širem šibenskom području. Vrlo brzo uočio sam da izgled Morinjskog zaljeva odgovara podatcima iz Putopisa, odnosno da se utvrda Ribnica s velikom sigurnošću može identificirati s ostatcima utvrde Kaštel Andreis u današnjem naselju Jadrtovac kod Šibenika (Karta 1). Olakšavajuća

10 Nenad Moačanin, O problemima kartografske identifikacije obavijesti iz osmanskih popisa bosanskih krajišta, Radovi Zavoda za hrvatsku povijest, sv. 32-33, Zagreb, 1999. - 2000., 345.

11 Kao dodatni argument ističe postojanje toponima Grižinica nedaleko od utvrde Dračevac u Jasenicama: Tomislav ŠARLIJA, Jasenice pod vlašću Osmanlija i Mlečana od XVI. do konca XVIII. stoljeća, Povijesni prilozi, sv. 43, 2012., 135 - 175, bilj. 43.

12 T. ŠARLIJA, Jasenice pod vlašću Osmanlija, 143. 
okolnost za brzu ubikaciju bila je ta što je šibenski konzervator Ivo Glavaš nedavno objavio rad o ostatcima utvrde u Jadrtovcu. ${ }^{13}$

\section{MORINJSKI ZALJEV U RANOM NOVOM VIJEKU}

Morinjski zaljev ili Morinje sastoji se od plitkog zaljeva površine do $5 \mathrm{~km}^{2}$ i uskog kanala, dugog oko 2,5 km, koji ga spaja s otvorenim morem. Kanal je na ulaznom dijelu širok $140 \mathrm{~m}$, dok na spoju sa zaljevom kod Jadrtovca doseže 350 $\mathrm{m}$. Na njegovu središnjem dijelu, uz istočnu obalu, nalazi se mali otok površine manje od 1 ha (Slika 1). Podatci iz povijesnih izvora potvrđuju da je od razdoblja ranog novog vijeka do danas u Morinjskom zaljevu došlo do određenih hidrogeomorfoloških promjena, ponajprije uzrokovanih podizanjem morske razine i izvođenjem različitih infrastrukturnih radova. Najizraženije su promjene nasipavanje oko $1 \mathrm{~km}$ obale uz istočnu stranu kanala i potapanje najmanje jednog otoka u zapadnom dijelu zaljeva, odnosno ostataka solana uz njegovu sjevernu i sjeverozapadnu obalu.

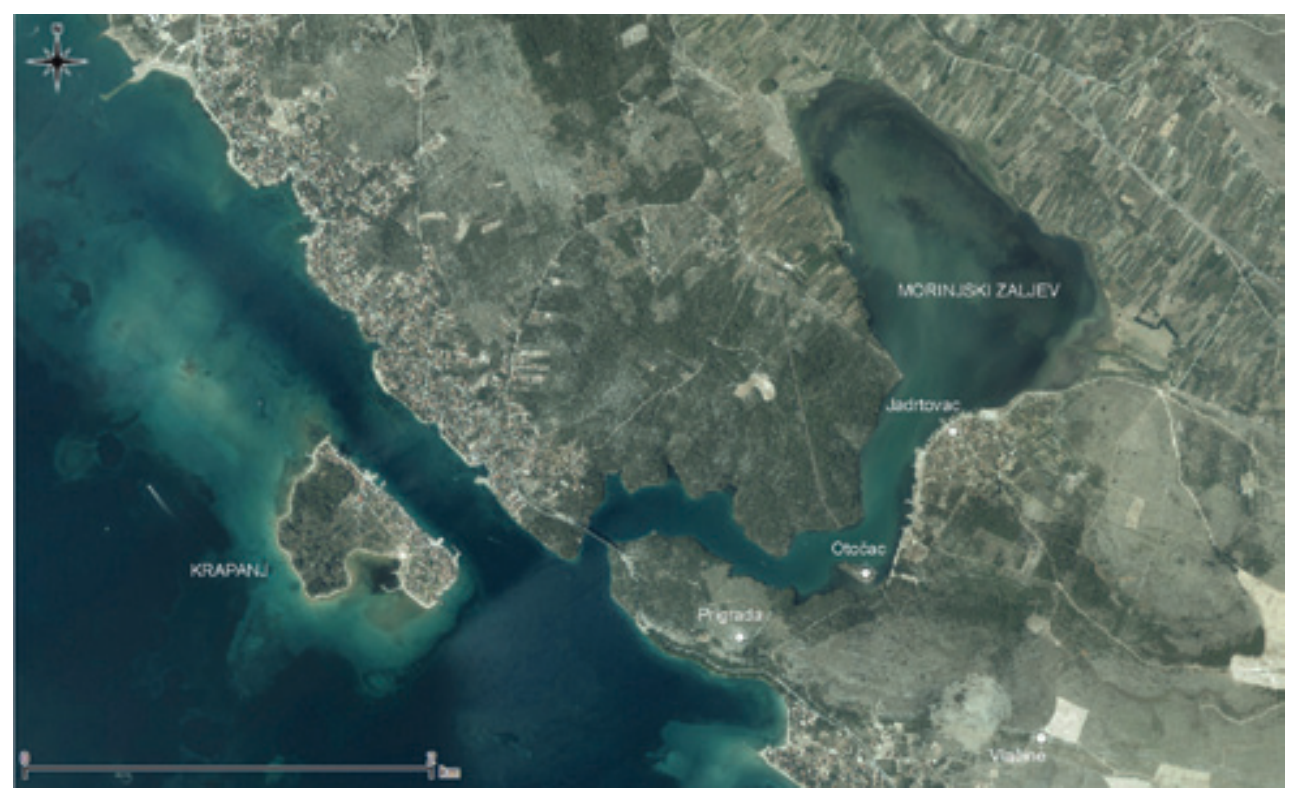

SLIKA 1. Zračni snimak područja Morinjskog zaljeva (izvor: geoportal.dgu.hr)

13 Ivo Glavaš, Kaštel Andreis u Zamurvi (Jadrtovcu) u Morinjskom zaljevu kod Šibenika, Godišnjak zaštite spomenika kulture Republike Hrvatske, sv. 39, Zagreb, 2016., 125 - 130. 
Prvi detaljniji prikaz Morinjskog zaljeva nalazi se na kartama koje je u drugoj polovici 16. stoljeća izradio Šibenčanin Martin Rota Kolunić (1520. - 1583.). ${ }^{14} \mathrm{Na}$ karti iz 1570. godine prikazan je zaljev (Lago de Morigne) i kanal koji ga povezuje s otvorenim morem (Karta 2). U zapadnom dijelu zaljeva prikazan je manji otok s crkvom. Uz istočni rub zaljeva označeno je selo Zamurva (Zamurua) i utvrda s dvije kule, što se smatra najstarijim prikazom utvrde Kaštel Andreis. ${ }^{15} \mathrm{Na}$ brdima iznad Donjeg polja (CAMPO DISOTO) prikazane su šibenske komunalne utvrde Parisotto (C. de Parisoto) i Vrpolje (Vardipogle). ${ }^{16}$

Isti je autor izradio novu verziju karte za potrebe mletačkog izolara iz 1571. godine. ${ }^{17} \mathrm{Na}$ njoj je izostavljen prikaz utvrde u Morinjskom zaljevu, a od novih detalja najznačajniji su prikazi solana (Saline) uz zapadni te ušće potoka Ribnik (Ribnich) uz istočni rub Morinjskog zaljeva (Karta 3). Na istočnoj su strani označeni i položaji vinograda (Vigne) i sela Zaton (Zaton).
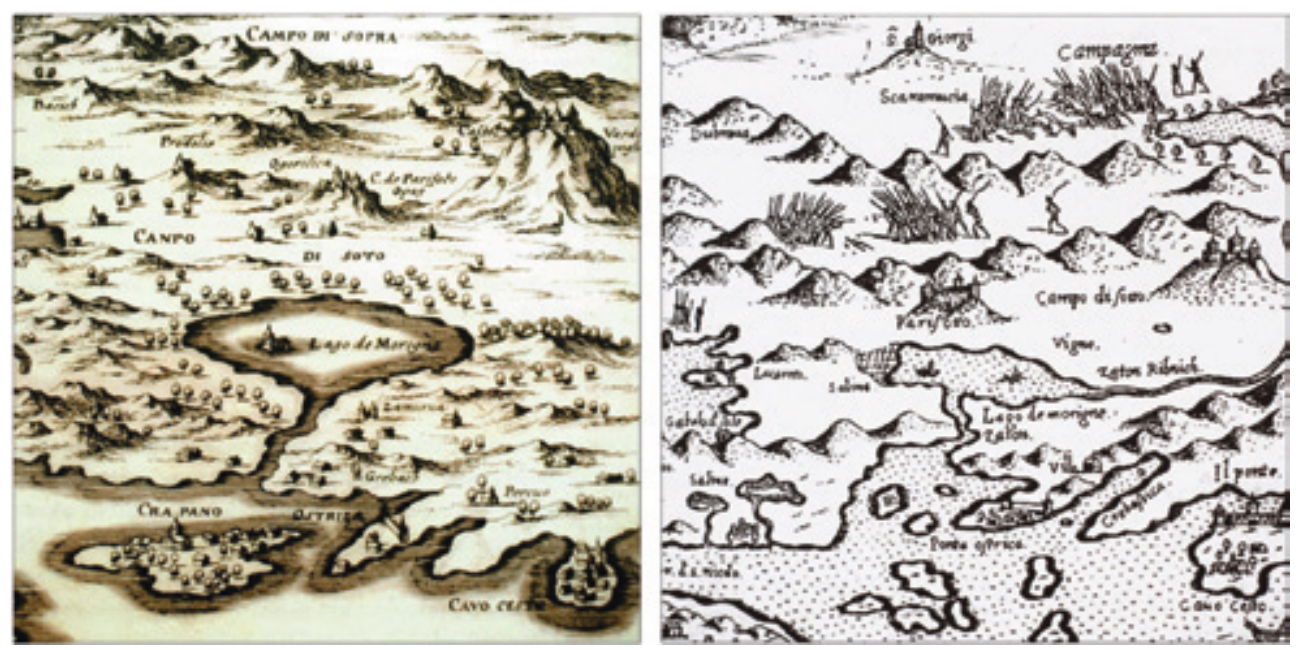

KARTA 2 - 3. Isječci zemljovida iz 16. stoljeća s prikazom Morinjskog zaljeva (M. Slukan Altić, $2007,37,40)$

14 Mirela Slukan Altić, Povijesna geografija rijeke Krke: kartografska svjedoćanstva, Zagreb, 2007. 35 .

15 I. Glavaš, Kaštel Andreis u Zamurvi, 126.

16 Ovo su dvije glavne utvrde za zaštitu Donjeg polja, odnosno jugoistočnog šibenskog područja koje je imalo veliku važnost za prehranjivanje šibenske komune. Najnovije podatke o ovim utvrdama vidi u: Ivo Glavaš, Ivo ŠprLJAN, Utvrde u šibenskom campo di sotto - ostaci kaštela Vrpolje i kule Parisotto, Portal - Godišnjak Hrvatskog restauratorskog zavoda, sv. 7, Zagreb, 2016., 135 - 146.

17 M. Slu kan Altić, Povijesna geografija rijeke Krke, 39. 
Evlija Čelebi zaljev je opisao jako kratko i informativno: „Ali kako se zapadna strana ovog grada nalazi na moru, on predstavlja veliko pristanište. To je tijesan kanal kao jedna vrata na Bosporu. Prostran je tako da u toj luci može pristati pet stotina lađa. U sredini kanala na jednoj litici ima mala kula. ${ }^{\text {"18 }}$ Nigdje ne spominje plitki zaljev u kojemu su se nalazile solane i otok s crkvom, očito zbog toga što to područje nije imalo nikakav utjecaj na tijek bitke. Osim toga, crkva je vjerojatno već bila porušena u ranijem osmanlijskom napadu, ${ }^{19}$ dok je za solane poznato da su već odavno bile napuštene. ${ }^{20}$

Evlija više puta spominje maleni otok smješten u središnjem dijelu Morinjskog kanala. Na gore navedenim novovjekovnim kartama ovaj otok nije prikazan, a razlog zbog kojega ga Evlija spominje je taj što je imao znatan utjecaj na tijek bitke. Iz njegova opisa saznajemo da se na otoku nalazila malena kula, a pored nje je bilo pristanište za brodove. Na suvremenim hrvatskim kartama otok nosi naziv Otočac, dok je na austrijskim kartama iz 19. stoljeća označen kao Scuglich ili Skuljic. Povjesničar J. Kolanović uz njega smješta solanu koja se u srednjovjekovnim i novovjekovnim dokumentima spominje pod nazivom „saline de Ottozaz in Morigne“ ${ }^{21} \mathrm{Na}$ jugoistočnom dijelu otoka nalazi se manja poljoprivredna površina do koje vodi oko $40 \mathrm{~m}$ dugi potopljeni nasip, koji je prohodan samo za vrijeme jačih oseka.

\section{UTVRDA RIBNICA (KAŠTEL ANDREIS)}

Evlija je utvrdu u Morinjskom zaljevu opisao dosta sažeto s nekoliko osnovnih informacija. Na samom početku navodi da su do nje stigli idući od Šibenika pola sata prema istoku, pri čemu su prešli preko brdâ i vinogradâ. ${ }^{22}$ Ako pretpostavimo da se to odnosi na jahanje na konju, onda ovaj podatak možemo smatrati prilično preciznim jer se ostatci utvrde u Jadrtovcu nalaze oko $8 \mathrm{~km}$ jugoistočno od središta Šibenika. Dalje navodi da se utvrda nalazi na granici kliškog i krčkog

18 E. Čelebi, Putopis, 183.

19 Šibenski je povjesničar Franjo Difnik (Divnić) zabilježio da su već 1646. godine, na samom početku Kandijskog rata, u osmanskim napadima, zajedno s Kaštelom Andreis, porušene crkve u šibenskom Donjem polju: Franjo Difnik, Povijest kandijskog rata u Dalmaciji, Split, 1986., 98.

20 Od 15. stoljeća u Morinju se spominju solane Otočac, solane Samostana sv. Spasa i Opatije sv. Nikola, ali sve su prestale s radom 1566. godine: Josip KolAnović, Šibenik u kasnome srednjem vijeku, Zagreb, 1995., 200. Podizanje morske razine i djelovanje prirodnih procesa doveli su do potapanja solana, ali ostatci solnih bazena još uvijek su vidljivi uz sjeverni i sjeveroistočni rub zaljeva (najbolje su vidljivi na satelitskim snimkama Google Eartha od 12. 3. 2014. godine).

21 J. Kolanović, Šibenik u kasnome srednjem vijeku, 200, bilj. 76, 203.

22 E. ČElebi, Putopis, 183. 

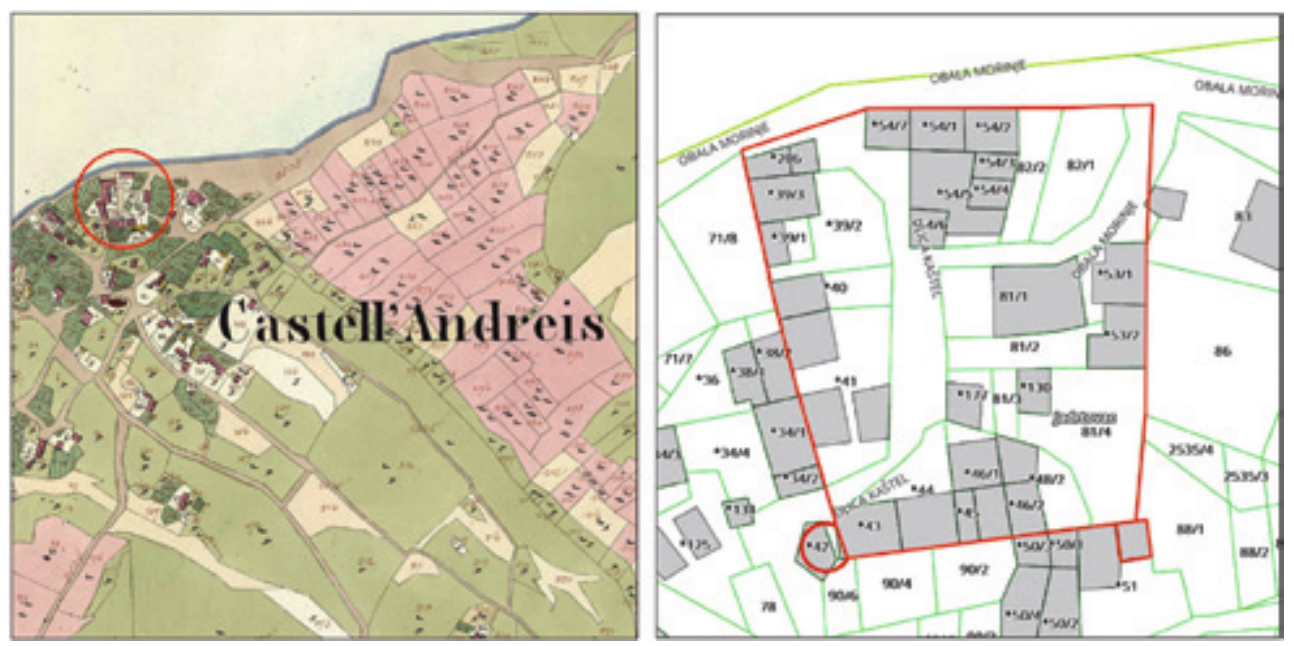

KARTA 4 - 5. Kaštel Andreis na austrijskom katastru iz 1825. godine s označenim položajem ostataka utvrde i njezin mogući izgled označen na suvremenom hrvatskom katastru (izvori: mapire. eu i geoportal.dgu.hr)

sandžaka te da su iz nje poduzimani uskočki napadi na gradove Sinj i Knin. ${ }^{23}$ Smještaj je naveden samo okvirno jer se granica sandžaka većim dijelom nalazila na rijeci Krki, dok u istinitost podatka o pohodima na osmansko zaleđe ne treba sumnjati jer je poznato da je još od 16. stoljeća utvrda bila naseljavana Morlacima koji su svojim pljačkaškim pohodima nerijetko uzrokovali napetosti između Mletačke Republike i Osmanskog Carstva.

Evlija navodi da se utvrda nalazi na niskoj klisuri, na samoj morskoj obali, a iz opisa njezina osvajanja saznajemo da joj je jedna strana bila okrenuta prema moru te da su na njoj postojala vrata koja su vodila do pristaništa za brodove. ${ }^{24} \mathrm{Za} \mathrm{utvrdu}$ kaže da je četverokutnog oblika, sazidana od kamena, dodajući da je simpatična i divna kao bijeli labud. ${ }^{25}$ Druge podatke o njoj donosi samo posredno, na primjer kada navodi da su branitelji zauzeli obrambene položaje na bedemima, zatim da je u njoj zaplijenjena velika količina oružja, među kojem je bilo i šest topova, te da su muslimanski ratnici, nakon pljačke i paleži, izvalili i bacili velika željezna vrata (demir kapuların). ${ }^{26}$ Ova su se vrata najvjerojatnije nalazila na glavnom ulazu u utvrdu, čije je ostatke I. Glavaš prepoznao u zapadnom obrambenom zidu, nedaleko od ostataka polukružne kule. ${ }^{27}$

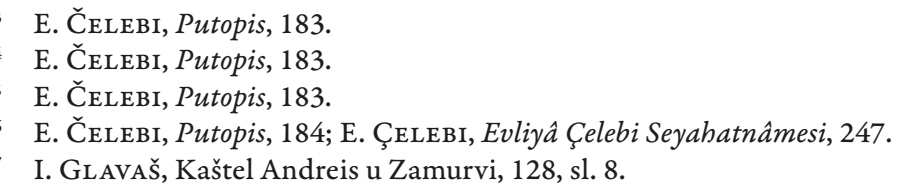


Sačuvani ostatci utvrde potvrđuju da je Evlijin opis točan, a jedino što pogrešno navodi je da se zapadna, umjesto sjeverna strana nalazila na moru. Utvrda je najvjerojatnije imala trapezoidni oblik, sa samo dvije obrambene kule na južnoj, najužoj strani, od kuda se očekivao neprijateljski napad (Karta 5). ${ }^{28}$ Ostatci sjevernog zida nisu sačuvani, zbog čega se bez arheoloških iskopavanja ne može utvrditi njezina točna veličina. ${ }^{29}$ Ipak, prilično je izgledno da se sjeverni rub utvrde nalazio na mjestu pročelja današnjih objekata uz cestu, što je i linija nekadašnje morske obale. ${ }^{30}$

Utvrdu na istočnoj obali Morinjskog zaljeva i nadomak Donjem polju sagradili su članovi poznate trogirske plemićke obitelji Andreis, čiji se pripadnici na šibenskom području spominju od 15. stoljeća. Oni su, kao i brojni drugi plemići, sagradili utvrdu radi zaštite svojih posjeda od sve učestalijih osmanskih pljačkaških pohoda. U dokumentu iz 1528. godine prvi se put spominje utvrda $\mathrm{s}$ dvije kule. ${ }^{31} \mathrm{U}$ većini se povijesnih izvora naziva Castel Andreis, a isto je ime dobilo i naselje koje se kasnije razvilo uz njezine ostatke (Karta 4). Tijekom druge polovice 19. stoljeća naselje je dobilo službeni naziv Jadrtovac, što je pučka, hrvatska varijanta dotadašnjeg imena. ${ }^{32}$ Evlija koristi naziv Ribniçse (Ribnica), što je izvedeno od imena izvora Ribnik koji se nalazilo nedaleko od utvrde. ${ }^{33}$ Suvremeni šibenski povjesničar Franjo Difnik (Divinić) utvrdu naziva Zamurva, po imenu nestalog sela u kojemu je bila izgrađena. ${ }^{34}$

\section{NAPAD OSMANLIJA NA MORINJSKI ZALJEV 1660. GODINE}

Napad Osmanlija na utvrdu Ribnica ili Kaštel Andreis dogodio se u kasno ljeto 1660. godine, u sklopu vojnog pohoda koji je na mletački posjed u Dalmaciji

28 I. Glavaš, Kaštel Andreis u Zamurvi, 129, sl. 10.

29 I. Glavaš navodi da je utvrda mogla biti velika od 1900 do 2600 m²$^{2}$ I. GLAvAš, Kaštel Andreis u Zamurvi, 129.

30 Krsto Stošić naveo je da su još 1758. godine ostatci zidina sezali do morske obale: Krsto STošić, Sela šibenskog kotara, Šibenik, 1941., 62. U međuvremenu je došlo do nasipanja obale, ponajprije radi izgradnje ceste, a poslije toga i zbog gradnje niza manjih pristaništa za brodove, zbog čega je sadašnja morska obala udaljena najmanje $20 \mathrm{~m}$ od ostataka utvrde.

31 Federico Antonio Galvani, Il Re d'armi di Sebenico con illustrazioni storiche, sv. 1-2, Venecija, 1884., 68.

32 K. STоšı́, Sela šibenskog kotara, 61.

33 Nepresušni izvor vode Ribnik izvire uz južni rub polja, oko $1 \mathrm{~km}$ istočno od Jadrtovca, a ulijeva se u Morinjski zaljev oko $550 \mathrm{~m}$ sjeveroistočno od utvrde. U drugoj polovici 18. stoljeća opisao ga je A. Fortis, navodeći da njegove vode u zaljev privlače veliki broj riba: Alberto Fortis, Put po Dalmaciji, Zagreb,1984., 111.

$34 \quad$ F. Difnik, Povijest kandijskog rata, 98. 
pokrenuo bosanski beglerbeg Melek Ahmed-paša. To zasigurno nije bio prvi napad na ovu utvrdu jer je po tvrdnjama F. Difnika ona već bila zapaljena 1646. godine. ${ }^{35}$ Sam Evlija o tom pitanju daje kontradiktorne podatke jer na početku navodi da je utvrda mnogo puta padala u osmanske ruke, dok u nastavku piše da se do tada na nju nije napadalo jer je izolirana i udaljena od putova. ${ }^{36}$

Prije napada na područje Morinjskog zaljeva, osmanska vojska, kojom je zapovijedao Jusuf-ćehaje (Yûsuf Kethüdâ), utaborila se nedaleko od Šibenika. Po opisu položaja i kretanja postrojba, najizglednije je da im se glavni tabor nalazio na području današnjeg sela Dubrava. Od tuda su poduzimali manje pljačkaške pohode sve do nadomak gradskih bedema Šibenika, koji ovoga puta nisu ni pokušali napadati jer je bio izuzetno dobro utvrđen. Njihov je glavni cilj bila pljačka i temeljito uništavanje svih okolnih posjeda, pri čemu su uspjeli osvojiti i spaliti nekoliko manjih utvrda kao što su Kamen, Marina kod Trogira i Kaštel Andreis u Morinjskom zaljevu.

Evlija piše da su iz tabora krenuli u napad na utvrdu Ribnica te da su nakon njezina osvajanja prenoćili u blizini Šibenika. Od tuda su sljedećeg dana prešli na područje Danilova (Danilo) ${ }^{37}$ gdje su se utaborili i prenoćili, planirajući krenuti na pohod prema Marini kod Trogira. Međutim, u nastavku opisuje neuspjeli pohod prema utvrdi Mandalina, koja se nalazi na južnom kraju šibenskog zaljeva. U ovom se slučaju vjerojatno radi o pogrešnom navođenju slijeda događaja, što je bio čest slučaj uzrokovan Evlijinim naknadnim bilježenjem događaja i mjesta kroz koja je putovao. ${ }^{38}$

Poznato je da je Evlija u svoje opise znao ubaciti i različite sadržaje, među kojima su i neki komični događaji, kojima je želio zabaviti čitalačku publiku. ${ }^{39}$ Čini se da je jedan takav događaj opisao kao uvod u bitku kod Ribnice. Naime, Evlija tvrdi da su izvidnici u jednom vinogradu u šibenskoj okolici uhvatili pijanca te ga doveli u svoj tabor. On im je u zamjenu za svoju slobodu obećao pokazati veliki plijen te ih je trčeći odveo do utvrde Ribnica i na taj način stekao slobodu. ${ }^{40}$

Sam napad na Morinjski zaljev dogodio se iznenadno jer je u berbi grožđa zatečeno brojno stanovništvo koje se nije uspjelo skloniti u utvrdu ili vratiti na usidrene brodove, već su se posakrivali po okolnim vinogradima. Čak ni oni

35 F. Difnik, Povijest kandijskog rata, 98.

36 E. Čelebi, Putopis, 183.

37 Neki autori Danilovo identificiraju s Kosovim poljem: N. Moačanin, K. Jurin StarČEvić, „Novi“ Evlija Čelebi, 85.

38 N. MoaČanin, K. Jurin StarČEvić, „Novi“ Evlija Čelebi, 80.

39 N. MoaČanin, K. Jurin StarČEvić, „Novi“ Evlija Čelebi, 81.

40 E. Čelebi, Putopis, 184. 
koji su ostali na brodovima usidrenima uz otok u sredini Morinjskog kanala nisu uspjeli pobjeći prema otvorenom moru. $U$ tome su ih spriječila dva veća vojna odreda naoružana puškama, na način da su zauzeli položaje s obje strane uskog kanala. Premda Evlija navodi da su vojnici na te položaje poslani tek kad su brodovi počeli bježati prema otvorenom moru, to se ne čini posve uvjerljivim, već bi ovaj detalj mogao ukazivati da je napad bio unaprijed isplaniran.

Nakon što nisu uspjeli pobjeći prema otvorenom moru, većina se brodova vratila i usidrila kod Otočca u sredini kanala, a nekoliko ih je doplovilo i usidrilo se uz sjevernu stranu utvrde, gdje su se već nalazili neki drugi brodovi (Karta 6). Oko 200 hrabrih hrvatskih ratnika (Hirvat yiğitleri), koji su se borili u redovima osmanske vojske, otplivalo je do pristaništa kod utvrde i otelo tri najveća broda..$^{41}$ Od otetih jarbola, vesala i konopa načinili su ljestve, a iz okolnih su vinograda dovaljali velike drvene bačve te ih prislonili uz utvrdu, što im je omogućilo da se popnu na bedeme, gdje je sat vremena trajala bitka s braniteljima i njihovim zapovjednikom uskokom Šarićem (şarik)..$^{42}$ Ovi podatci potvrđuju da napadači nisu imali opsadne sprave, već im je snalažljivost i višestruka brojčana nadmoć omogućila da relativno lako osvoje utvrdu. Osim toga, smatra se da je ona bila izgrađena na zastarjeli način, s glavnim ciljem da zaštiti okolno stanovništvo od iznenadnih pljačkaških napada te da nije bila prilagođena dugotrajnoj opsadi, a pogotovo ne obrani od ozbiljnijeg artiljerijskog napada. ${ }^{43}$

Zapovjednik obrane Šarić i preostali branitelji dali su se u bijeg na način da ih je po 20 do 30 uskočilo u nekoliko brodova usidrenih uz sjevernu stranu utvrde. Napadači su se popeli na bedeme i na njih otvorili vatru, tako da ih je samo po pet ili šest na svakom brodu uspjelo doploviti do otoka u sredini kanala. ${ }^{44}$ Nakon toga su se osmanski vojnici ukrcali na pet ili šest brodova usidrenih kod utvrde i krenuli u napad na otok. Šarić je s preostalim ljudima ukrcanim na pet do šest brodova pokušao pobjeći, međutim kako se nisu mogli probiti prema otvorenom moru, namjerno su se nasukali na kopno gdje su ih osmanski vojnici brzo pohvatali i porobili. ${ }^{45}$

Manji je broj ljudi ostao na tri broda usidrena pored otoka u kanalu, no i oni su uskoro bili napadnuti i porobljeni. Od devet većih i manjih brodova kojima su pokušali bježati samo se jedan uspio spasiti bijegom na otvoreno more, a mnogi koji su se na njima nalazili sami su skočili u more i utopili se. Evlija na kraju

\footnotetext{
41 E. Čelebi, Putopis, 184; E. Çelebi, Evliyâ Çelebi Seyahatnâmesi, 246.

42 E. Čelebi, Putopis, 184; E. Çelebi, Evliyâ Çelebi Seyahatnâmesi, 246.

43 I. Glavaš, Kaštel Andreis u Zamurvi, 129.

44 E. Čelebi, Putopis, 184.

45 E. Čelebi, Putopis, 184.
} 


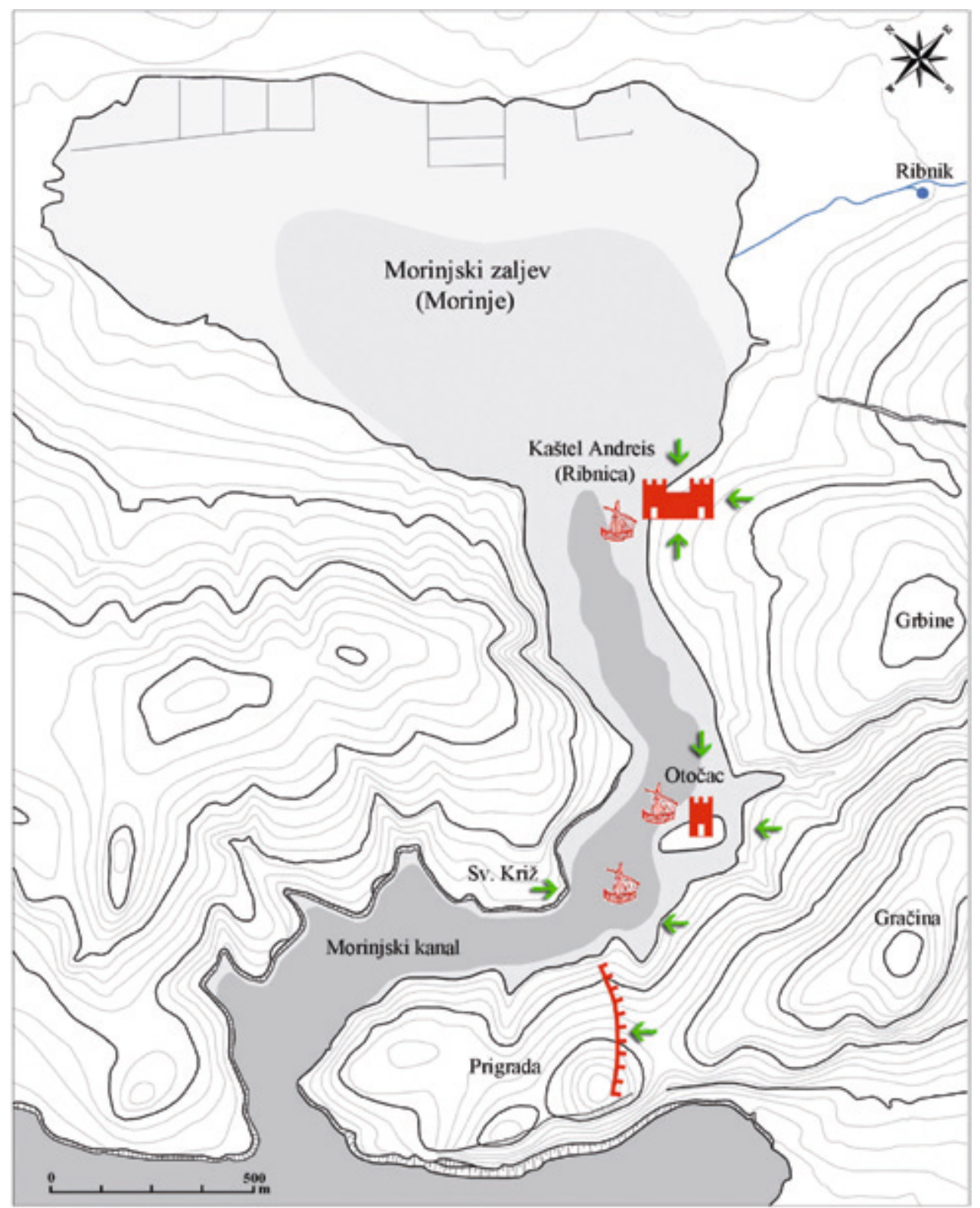

KaRTa 6. Prikaz vojnih operacija u Morinjskom zaljevu u ljeto 1660. godine (izradio: Š. Vrkić) 
navodi da je ukupno 29 brodova, nakon što su iz njih opljačkali oružje i opremu, privezano jedan za drugi i spaljeno u moru pored utvrde. Nakon toga su pohvatani preostali ljudi, žene i djeca koji su se skrivali po okolnim vinogradima. Evlija je njihovo hvatanje i porobljavanje slikovito usporedio s kokoši koja zoblje proso. ${ }^{46}$

Raniji su autori najviše sumnjali u točnost Evlijinih brojčanih podataka, ali sada je poznato da su brojni netočni podatci bili rezultat prepisivačkih i tiskarskih pogrešaka, odnosno da je on u tom pogledu prilično točan i pouzdan. ${ }^{47}$ To se može vidjeti i po broju brodova za koje je na početku naveo da ih je u luci bilo usidreno tridesetak te da je od njih samo jedan uspio isploviti prema otvorenom moru, dok je preostalih 29 spaljeno pored utvrde. Nema razloga sumnjati ni u ostale brojčane podatke, na primjer kada se navodi da je iz utvrde opljačkano šest topova ili da je kod vinograda poginulo sedam osmanskih ratnika itd. Što se tiče broja vojnika i zarobljenih ljudi, čini se da ti podatci nisu egzaktni, već da se navode općeniti brojevi, na što upućuje Evlijino često korištenje broja 500. Tako navodi da je u luci moglo pristati 500 brodova, da je na lijevu i desnu stranu zaljeva poslano 500 vojnika te da se u vinogradu utvrdilo 500 ljudi.

Zanimljivo je i pitanje tipova brodova koji su korišteni u bitci u Morinjskom zaljevu. Evlija na početku navodi da su u kanalu oko otočića bili usidreni brodovi (kayıklar), fregate (firkate) i jedrilice (2skanpaviyeler). ${ }^{48}$ Očito se radilo o različitim tipovima plovila koje su u ono vrijeme koristili lokalni stanovnici. Međutim, kada kasnije opisuje tijek bitke, Evlija spominje isključivo fregate. To je naziv koji se zadnjih nekoliko stoljeća koristio za ratne brodove različitih veličina. U ovom se slučaju najvjerojatnije radilo o plovilima sličnim uskočkim gajetama, brodovima srednje veličine s jarbolom i veslima, ponekad naoružanih jednim topom, jer to je tip broda koji se najčešće koristio na području srednjeg Jadrana u drugoj polovici 17 . stoljeća. ${ }^{49}$

\section{UTVRĐENI VINOGRAD}

Evlija piše da se završna ratna epizoda odigrala u vinogradu iza brdâ od kuda su se začuli povici „Allah, Allah“. Iako nije bio osobno prisutan, opisao je događaj u kojemu se veći broj ljudi, po njegovim tvrdnjama njih 500, utvrdio u ozidanom vinogradu, jer prethodno nisu uspjeli brodovima pobjeći prema otvorenom

\footnotetext{
46 E. Čelebi, Putopis, 184; E. Çelebi, Evliyâ Çelebi Seyahatnâmesi, 246.

47 N. Moačanin, K. Jurin Starčević, „Novi“ Evlija Čelebi, 11.

48 E. ÇElebi, Evliyâ Çelebi Seyahatnâmesi, 246.

49 Mithad Kozličić, Hrvatsko brodovlje, Split, 1993., 65, sl. 9
} 
moru. Na njih je poslan odred vojske pod vodstvom Smail-alajbega (İsmấîl alaybeği), koji ih je tek nakon žestoke borbe uspio svladati, pri čemu je 60 ljudi zarobio. Nakon završetka bitke do utvrde su dovedeni zarobljenici i prenijeta tijela sedmorice poginulih osmanskih ratnika. ${ }^{50}$

Gdje se točno nalazio vinograd čiji su zidovi bili veliki kao bedemi, za sada nije moguće pouzdano utvrditi. Ako pretpostavimo da je ugroženo stanovništvo pobjeglo u suprotnom smjeru od napadača i opsjednute utvrde, onda taj lokalitet treba tražiti na južnoj strani. ${ }^{51} \mathrm{Na}$ tom krškom području danas postoji više lokaliteta s napuštenim vinogradima, od kojih su neki bili ograđeni masivnim suhozidima. Među njima se posebno ističe vinograd iznad predjela Vlačine u Žaboriću, smješten na strateškom položaju uz rub litice. ${ }^{52}$

Još se jedan lokalitet ističe svojim strateškim položajem. Radi se o poluotoku Prigrada, koji se nalazi uz južnu stranu Morinjskog kanala, oko 1,3 km jugozapadno od Jadrtovca. Već u prapovijesnom razdoblju poluotok je prezidan oko $300 \mathrm{~m}$ dugim suhozidnim bedemom, zbog čega je i dobio sadašnji naziv Prigrada. Ovaj je lokalitet prvi opisao arheolog Zlatko Gunjača interpretiravši ga kao refugij (Karta 7 ). ${ }^{53}$ Na sličan su način građena i neka utvrđenja u mlađim razdobljima. ${ }^{54}$ Tijekom druge polovice 20. stoljeća izgrađen je Morinjski most, preko kojega prelazi Jadranska magistrala (D8), čime je poluotok povezan sa suprotnom obalom. Međutim, u svim starijim razdobljima to je bilo izolirano i nepristupačno mjesto, zaštićeno morem i masivnim bedemom pa je za očekivati da bi stanovništvo, koje se iznenada našlo u opasnosti, ponajprije potražilo zaklon na tom lokalitetu. ${ }^{55}$

50 E. Čelebi, Putopis, 185; E. Çelebi, Evliyâ Çelebi Seyahatnâmesi, 247.

51 Ne može se isključiti mogućnost da se opisani događaj zbio istočno od Jadrtovca. Naime, F. Difnik zabilježio je da su se tijekom ovog pohoda Krapljani i Vrpoljani neuspješno pokušali oduprijeti osmanskim napadačima nedaleko od ruševina vrpoljske utvrde, što bi se moglo odnositi na događaj koji je opisao Evlija: F. Difnik, Povijest kandijskog rata, 261.

52 Moguće je da vinograd potječe iz novijeg razdoblja jer ga ne nalazimo ucrtanog na austrijskom katastru iz 1825. godine.

53 Zlatko GunjačA, O kontinuitetu naseljavanja na području Šibenika i najuže okolice, u: Šibenik: spomen zbornik o 900. obljetnici, (ur. Slavko Grubišić), Muzej grada Šibenika, Šibenik, 1976., 36, T. XIV, XXIV.

54 Najbolji takav primjer na šibenskom području je utvrda Oštrica kod Grebaštice izgrađena krajem 15. stoljeća. I u ovom je slučaju poluotok prezidan visokim bedemom, koji je u vrijeme osmanskih napada pružao zaštitu stanovništvu okolnih mjesta, koji su se tamo sklanjali sa svojim stadima: K. STOŠić, Sela šibenskog kotara, 250 - 251.

55 Na južnom rubu poluotoka, nedaleko od bedema, nalazi se najveće uzvišenje od 73,5 m n/v, u čijoj su blizini stoljećima postojali vinogradi. U dokumentu iz 1670. godine, među mjestima koja su pripala šibenskom kotaru, navodi se i Pridraga „na ustima Morinja“: K. STošıć, Sela šibenskog kotara, 10. 


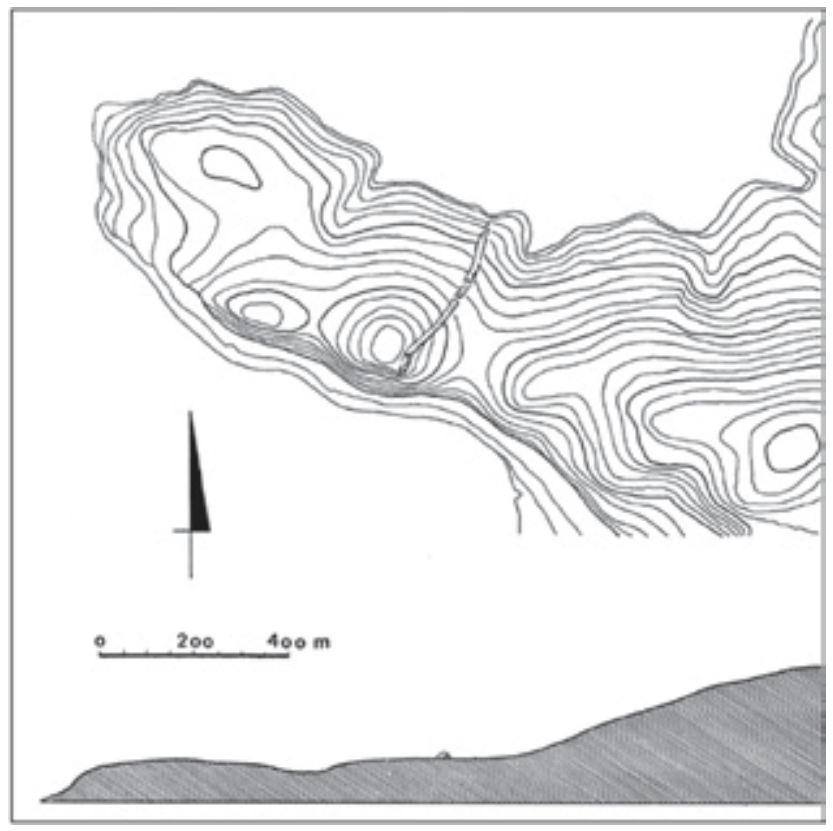

KARTA 7. Prapovijesni lokalitet Prigrada na ulazu u Morinjski zaljev (Z. Gunjača, 1976, T. XIV)

\section{USKOČKI HARAMBAŠA CVITKO ŠARIĆ}

Zapovjednik obrane utvrde Ribnica ili Kaštela Andreis bio je zanimljiva povijesna ličnost. Radi se o uskoku Šariću (şarik), kojega Evlija više puta spominje tijekom bitke i jednom prilikom tijekom kasnijeg otkupa zarobljenika. ${ }^{56}$ Prevoditelj H. Šabanović napomenuo je da nije poznato o kojemu se uskoku radi, a kao jednu od mogućnosti naveo je popa Šarića, koji je bio zarobljen nakon bitke kod Ribnika u Lici 1648. godine. ${ }^{57}$ Međutim, uvidom u povijesne dokumente iz razdoblja Kandijskog rata može se s velikom sigurnošću zaključiti da se radi o poznatom uskočkom harambaši Cvijanu ili Cvitku Šariću. ${ }^{58}$ Sačuvani dokumenti potvrđuju Evlijinu tvrdnju da se radi o bivšem osmanskom podaniku koji je prebjegao u mletačku službu. Tako se u izvještaju providura A. Vendramina iz 1644. godine prvi put spominje Cvitko Šarić (Cuitco Sarich), Morlak iz sela Strupnik u zadarskom zaleđu, koji je iz osvete za ubijenog magarca mletačkim podanicima Mirkovićima u selu Grusi 
posjekao vinograd. ${ }^{59}$ B. Desnica pretpostavlja da se on početkom Kandijskog rata, zajedno sa svojim gospodarima Durakbegovićima, povukao sa zadarskog područja u dalmatinsko zaleđe ili Bosnu, od kuda je kasnije prebjegao na šibensko područje, gdje se prvi put spominje 1652 . godine. ${ }^{60}$ Tih je godina zabilježen masovan prelazak kršćanskog stanovništva na mletačku stranu, stoga ne čudi što se Šarić odmetnuo od svojih dotadašnjih gospodara i prešao na šibensko područje, gdje je kasnije postao zapovjednik utvrde Kaštel Andreis i vođa svih šibenskih Morlaka.

Povjesničar Kristijan Juran ističe da je utvrda u Morinjskom zaljevu bila jedno od glavnih imigracijskih područja morlačkih prebjega iz dalmatinskog zaleđa te da je predstavljala jedan od tri ključna obrambena položaja na šibenskom kopnenom području. ${ }^{61}$ Poznato je da su još od 16. stoljeća plemići Andreis naseljavali morlačke obitelji na svoja opustošena imanja, protiv čega su se bunili šibenski građani jer su im doseljenici nanosili materijalne štete. ${ }^{62}$ Naseljavanje novog stanovništva bilo je neophodno jer je ono prijašnje uglavnom pobjeglo na otok Krapanj ili u šibenska predgrađa. Doseljenici su nerijetko svojim pljačkaškim pohodima uzrokovali nestabilnost na graničnom području između Mletačke Republike i Osmanskog Carstva. Tomu je vjerojatno pridonosila i činjenica što je Morinjski zaljev bio pogodna baza u kojoj su uskoci iz drugih krajeva mogli sidriti svoje brodove te od tuda nastavljati pljačkaške pohode u dalmatinsko zaleđe.

Krajem 1652. godine Cvitko Šarićje zajedno s drugim šibenskim harambašama sudjelovao u zarobljavanju bosanskog alajbega Jusuf-bega Filipovića, zbog čega su od providura G. Foskarinija zatražili tri turska roba s galija, kako bi ih mogli razmijeniti za svoje bližnje koji su se nalazili u osmanskom zarobljeništvu. ${ }^{63}$ Providur je posebno nagradio najzaslužnije za zarobljavanje Filipovića, među kojima je bio i Šarić, kojemu je tom prilikom dodijeljena mjesečna plaća u baškotu jer je već primao mjesečnu plaću u novcu. ${ }^{64}$ Od ove se godine imena Cvitka Šarića i njegove žene Dese često spominju u maticama pravoslavne crkve u Šibeniku, bilo kao kumovi ili kao roditelji petero krštene djece. ${ }^{65}$ Godine 1654 . njegovo se ime spominje među harambašama i uglednim šibenskim pravoslavcima koji su zatražili da se otac Kiril ne smjenjuje s mjesta šibenskog paroha. ${ }^{66}$

${ }^{61}$ Kristijan Juran, Morlaci u Šibeniku između Ciparskoga i Kandijskog rata (1570.-1645.), Povijesni prilozi, sv. 49, Zagreb, 2015., 173.

62 F. A. Galvani, Il Re d'armi di Sebenico, 86.

63 Boško DesnicA, Istorija kotarskih uskoka 1646-1684, sv. I, Beograd, 1950., 63 - 64.

64 B. DeSNICA, Istorija kotarskih uskoka, 64 - 65; B. DESNICA, Sabrana djela, 135.

65 B. DesnicA, Sabrana djela, 135.

66 B. DESNICA, Istorija kotarskih uskoka, $73-74$. 
Zahvaljujući Evliji Čelebiju doznali smo da je 1660. godine Cvitko Šarić bio zapovjednik obrane utvrde Kaštel Andreis te da je neposredno nakon njezina osvajanja zarobljen i odveden na područje Livna, od kuda ga je već iste godine otkupio predstavnik grada Šibenika ${ }^{67}$ Nakon povratka iz zarobljeništva Šarić se prvi put spominje 1662. godine u ispravi providura A. Cornera u kojoj mu se udovoljava molbi da se njegova mjesečna plaća od četiri dukata i primanje u baškotu prenesu na osmogodišnjeg sina Jovana ili Ivana Šarića (Zuanne Sarich). ${ }^{68}$ Krajem 1663. godine Šarić se istaknuo kao vođa pohoda u okolici Knina gdje su uspjeli spaliti veliku količinu sijena prikupljenog za proljetni vojni pohod na mletački teritorij. Zbog ovog poduhvata providur G. Contarini, koji Šarića oslovljava kao serdara i zapovjednika šibenskih Morlaka, udovoljava njegovoj molbi da se od kazne veslanja na galiji oslobodi osuđenik Jakov Vučić. ${ }^{69}$

U izvještaju dalmatinskog providura C. Cornara senatu 5. travnja 1666. godine Šarić se opisuje kao stari, odvažni i gramzivi harambaša, koji je smislio i organizirao morlački pohod na Cetinsku krajinu tijekom kojega je zarobljen serdar Stojan Janković. ${ }^{70}$ Ponovno se spominje 1668. godine u dva dokumenta koje je izdao providur A. Priuli. Prvi se put spominje u vezi potražnje jedne zaostale mjesečne plaće koja je u međuvremenu narasla na deset dukata. ${ }^{71}$ Drugi se put spominje kada je u ime svih šibenskih pravoslavnih Morlaka podnio pritužbu na ponašanje jednog katoličkog svećenika u Šibeniku, koji je zbog vjerske netrpeljivosti omalovažavao paroha Kirila i svakodnevno bacao otpad pored pravoslavne crkve. ${ }^{72}$ Godine 1672 . harambaša Cvitko Šarić više nije među živima, a kao njegov se nasljednik spominje sin Jovan Šarić. ${ }^{73}$

Ime harambaše Cvitka Šarića zabilježeno je u nekoliko narodnih pjesmama iz uskočkog ciklusa. Tako ga Andrija Kačić Miošić spominje u pjesmi o šibenskim vitezovima, ali ga smješta u pogrešan povijesni kontekst Morejskog rata. ${ }^{74}$ Spominje se i u nekim narodnim pjesmama koje je sredinom 19. stoljeća na svojim putovanjima zapisao Vuk Stefanović Karadžić. ${ }^{75} \mathrm{Na}$ njegovu zastupljenost

67 E. ČELEBI, Putopis, 193.

68 B. DESNICA, Istorija kotarskih uskoka, 109 - 110.

69 B. DesnicA, Istorija kotarskih uskoka, 117; B. DesniCA, Sabrana djela, 135 - 136.

70 B. DESNICA, Istorija kotarskih uskoka, $123-125$.

71 B. DESNICA, Istorija kotarskih uskoka, 132 - 133.

72 B. DESNICA, Istorija kotarskih uskoka, 135.

73 Kristijan Juran, Stari i novi stanovnici Šibenika i njegovih predgrada u drugoj polovici 17. i početkom 18. stoljeća, Šibenik, 2016., 43.

74 Andrija Kačıć Mıošıć, Djela Andrije Kačića Miošića (priredio za tisak i uvod napisao Tomo Matić), knjiga 1, Zagreb, 1942., 493.

75 Vuk Stefanović KARADžić, Srpske narodne pjesme, sv. III, Beograd, 1985., 184 - 189, 189 - 196, 196. 
u epskim narodnim pjesmama osvrnuo se B. Desnica, napisavši sljedeće: „Ovom drskom i grabljivom šibenskom harambaši narodna pjesma nije dodijelila odvojeno mjesto. Ni u jednoj od pesama uskočkog ciklusa, bar koliko je meni poznato, Šarić Cvijan nije nosilac glavne akcije. Njegove su uloge mahom sporedne i epizodne. Uzrok je tome valjda taj što je ta ličnost bila lišena onih idealnih svojstava koja su otvarala širom dveri narodne epopeje. Za njega su te dveri bile samo odškrinute, isto kao što su za druge, iako znatne, glasovite i za hrišćansku stvar zaslužne pobornike, ostale sasvim zatvorene. ${ }^{\text {“76 }}$

Unatoč tomu što ga narodna epika nije uvrstila u rang slavnih serdara 17. stoljeća, povijesna uloga harambaše Cvitka Šarića svakako se ne može okarakterizirati kao potpuno nevažna i epizodna. Tomu u prilog najbolje svjedoči činjenica da je za vrijeme trajanja Kandijskog rata postao zapovjednik svih šibenskih Morlaka. Ni njegovi vojni pothvati nisu potpuno zanemarivi, od pokušaja obrane utvrde Kaštel Andreis do kasnijih pohoda u dalmatinsko zaleđe. Mletačke su vlasti ga okarakterizirale kao gramzivog, najvjerojatnije zbog toga što je od njih nastojao maksimalno naplatiti sve svoje usluge, nastojeći osigurati egzistenciju svoje obitelji, ali i izvući korist za zajednicu šibenskih pravoslavnih Morlaka s kojom je trajno ostao usko povezan. Po svemu sudeći, Cvitko Šarić umro je prirodnom smrću, što je bila iznimka za tadašnje morlačke harambaše, doživjevši pri tome priličnu dob s obzirom na vrijeme u kojemu je živio i službu koju je obavljao.

\section{ZAKLJUČAK}

Ovim se skromnim radom još jedanput potvrđuje da je djelo Evlije Čelebija vjerodostojan i pouzdan izvor za povijest hrvatskih zemalja u osmanskom razdoblju, što će još više doći do izražaja kada na hrvatski jezik bude prevedena izvorna verzija Putopisa. Točnom ubikacijom utvrde Ribnica omogućena je detaljna rekonstrukcija osmanskog napada na Morinjski zaljev u ljeto 1660 . godine. Na taj je način rasvijetljen događaj važan za lokalnu povijest, a koji je do sada bio poznat samo po kratkoj bilješci suvremenog šibenskog povjesničara Franje Difnika. Otkriveno je i nekoliko zanimljivih lokaliteta koji bi u budućnosti mogli biti pomnije istraženi kao što su nepoznata kula na Otočcu u Morinjskom zaljevu, zatim utvrđeni vinograd u kojemu se odigrala završna ratna epizoda, a koji za sada nije pouzdano lociran, te položaj u moru pored utvrde gdje su 
spaljeni zarobljeni brodovi. Dobiveni su i novi podatci o harambaši Cvitku Šariću, serdaru i zapovjedniku šibenskih Morlaka iz razdoblja Kandijskog rata, za kojega do sada nije bilo poznato da je vršio službu zapovjednika utvrde Kaštel Andreis te da je nakon toga bio na kratko dospio u osmansko zarobljeništvo. 
Šime VRKIĆ

\section{LOCATION OF THE FORTRESS RIBNICA FROM EVLIYA ÇELEBI BOOK OF TRAVELS}

\section{SUMMARY}

The paper attempts to determine the location of the Ribnica fortress, whose conquest was described in detail by the famous Ottoman travel writer Evliya Çelebi (1611 - 1682). He did it in his extensive work Seyâhatnâme (travel-book), which once again proved to be an extremely credible source for the history of Croatian countries in the Ottoman period. Assuming that his descriptions and geographical information were relatively authentic, using the Google Earth web service, I found out that the appearance of the Bay of Morinj fully corresponded to the data from the travel book. In other words, Ribnica can definitely be identified with the remains of the Kaštel Andreis (Andreis fortress) in Jadrtovac near Šibenik. Its identification enabled a detailed reconstruction of the Ottoman attack on the Morinj Bay area in the summer of 1660, which so far has only been known from a brief note by the contemporary Šibenik historian Franjo Difnik. This attack took place as part of an Ottoman military campaign launched on a Venetian property by the Bosnian beglerbeg (military and civil governor) Melek Ahmed Pasha. A sudden attack during the grape harvest surprised a large number of pickers who did not manage to shelter in the fort or return to their ships, which had brought them to the bay, so they hid in the surrounding vineyards. Those who remained on the ships anchored in the bay attempted to flee heading for the open sea but were prevented by two military units armed with rifles, which took positions on either side of the narrow channel. Subsequently, most ships anchored off the islet in the middle of the channel, while a smaller number sailed to the fort and anchored along its northern rampart. Numerically superior attackers made makeshift siege devices and conquered the fort relatively quickly. Its defence was commanded by the defector Šarić (şarik), who is identified with the well-known brigand captain Cvitko Šarić, serdar and commander of the Šibenik Morlaks from the Kandian War. With the remaining defenders, he tried to escape by jumping on the ships anchored near the fort. However, since they could not make their way to the open sea, they were grounded and immediately captured, just like those who remained on the ships anchored near the island. Of the thirty ships that found themselves in the Bay of Morinj, only one managed to escape by fleeing to the open sea, while the remaining 29 were looted and burned in the sea by the near fort. According to Evlija's testimony, the final war episode 
took place in a vineyard close to the fort, where 500 people fortified themselves but failed to resist the superior Ottoman invaders. The highlighted possible locations where the final battle took place were the vineyard above the Vlačina area in Žaborić and the hill-fort on the Prigrada peninsula at the entrance to the Morinj bay.

Keywords: Evliya Çelebi, Kandian War, brigand captain Cvitko Šarić, Bay of Morinj, Jadrtovac, Kaštel Andreis, Prigrada. 